\title{
Ocorrência de Podridão Negra, Causada por Chalara elegans, em Raízes de Cenoura no Rio Grande do Sul
}

\author{
Marisa Dalbosco, Samira O. M. El Tassa \& Valmir Duarte \\ Departamento de Fitossanidade, Faculdade de Agronomia, UFRGS, Cx. Postal 15.100, CEP 90001-970, Porto Alegre, RS, \\ fax: (51) 3316-6016, e-mail: valmir@ufrgs.br
}

(Aceito para publicação em 04/11/2003)

Autor para correspondência: Valmir Duarte

\begin{abstract}
Ocurrence of black root, caused of Chalara elegans, in carrot rot in the State of Rio Grande do Sul

A black root rot in carrot (Daucus carotae), caused by

Chalara elegans, is reported for the first time in the State of Rio Grande do Sul, Brazil.

de podridão negra, com regiões de tecidos enegrecidos e deprimidos, contendo estruturas típicas do fungo. Assim, os postulados de Koch foram satisfeitos. As estruturas da fase imperfeita, diferentes das apresentadas no trabalho citado acima, foram comparadas com as apresentadas na bibliografia e mostraram tratar-se de C. elegans, agente causal da podridão negra de raízes de cenoura, sendo este o primeiro relato no RS. Estruturas do fungo estão armazenadas em água e conservadas a $-20{ }^{\circ} \mathrm{C}$.
\end{abstract}

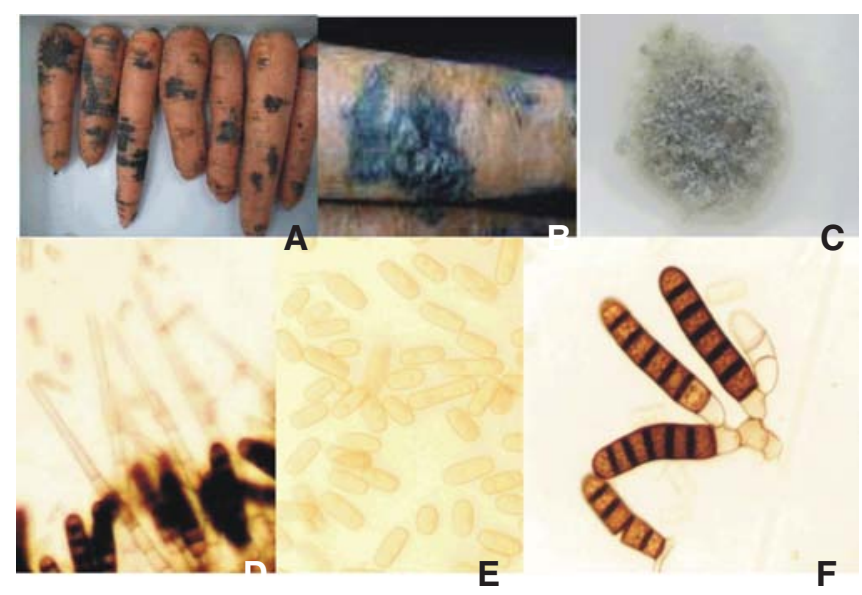

FIG. 1 - Sintomas de podridão negra (A e B), cultura do fungo em BDA+estreptomicina (C) e estruturas do fungo Chalara elegans (D), fiálides (10X); E, fialósporos (endoconídios) (40X); F, clamidosporos (aleuriósporos) (40X). Porto Alegre, 2003. 